\title{
Epidemiological patterns and risk factors associated with hepatitis B virus in Pakistani population
}

\author{
Yasir Waheed, Talha Bin-Rahat, Sher Zaman Safi, Ishtiaq Qadri \\ NUST Center of Virology and Immunology, National University of Sciences \& Technology, Islamabad \\ 44000, Pakistan.
}

\begin{abstract}
Hepatitis B virus prevalence is increasing in Pakistani population. National level estimates regarding the prevalence are missing. People are unaware of the risk factors involved in HBV transmission. The objective of the study was to review the prevalence, genotypes, and risk factors associated with HBV transmission in Pakistani Population. Literature search was done by using keyword HBV prevalence, genotypes and risk factors from Pakistani population at Pubmed, PakMediNet and Google scholar. Six different studies showed that the percentage prevalence of $\mathrm{HBV}$ in general population was $4.61 \pm 0.73 \%$, and 21 different studies showed the percentage prevalence of $2.33 \pm 0.46 \%$ in blood donors. High prevalence of $7.94 \pm 1.49 \%$ and $12.86 \pm 4.52 \%$ were observed in multi transfused and IDU populations. Six different studies showed that the major prevalent genotype was D. Awareness regarding various risk factors involved in-viral transmission was very low. Prevalence of HBV was very high in multitransfused populations due to non-implementations of international standards regarding blood transfusions. Barbers were unaware of the risk factors associated with their shops in viral transmission. Practices of unsterilized dental and surgical instruments and recycling of syringes were major factors in viral transmission. Massive awareness and vaccination programs are required to decrease the future burden of HBV from Pakistani population.
\end{abstract}

Keywords: Genotypes, HBV, Pakistan, prevalence, risk factors

Hepatitis B virus (HBV) infection is one of the most prevalent public health problems, especially in developing countries [1]. Two billion people are infected with HBV worldwide, out of which 350 million are chronic HBV patients. It is the tenth leading cause of deaths worldwide, with 500,000 to 1.2 million deaths per year caused by chronic hepatitis and cirrhosis, whereas 320,000 deaths per year are due to hepatocellular carcinoma [2]. In Pakistan, the prevalence of $\mathrm{HBV}$ is $3-4 \%$ and is considered an area of low endemicity [3, 4].

Pakistan is a developing country of 180 million people with low health and educational standard. According to the human development index of United Nations, it was ranked $134^{\text {th }}$ out of 174 countries [5]. In Pakistan, HBV infection rate is increasing daily.

Correspondence to: Yasir Waheed, Research Officer and PhD scholar, NUST Center of Virology and Immunology, National University of Sciences \& Technology, H-12 Sector, Islamabad (44000), Pakistan E-mail: yasir_waheed_199@hotmail.com
This might be due to lack of proper health facilities, poor economic status and lack of awareness about the transmission of HBV. Public health authorities are creating awareness about hepatitis through print and electronic media [6, 7], but tremendous efforts are still needed to increase the awareness regarding various risk factors involved in HBV transmission. In developing countries, due to non implementation of international standards regarding blood transfusion, reuse of injections, reuse of needles for ear and nose piercing, tattooing, injecting drug users, shaving from barbers, and unsterilized dental and surgical instruments are the main source of transmission of viral hepatitis [8]. This article briefly describes the prevalence, genotypes, and risk factors associated with HBV transmission in Pakistani population.

\section{Material and methods Literature search}

Articles were searched in Pubmed, Google scholar and PakMediNet (for non-index Pakistani journals), 
by using key words such as Prevalence of HBV in Pakistan, epidemiological patterns of HBV in Pakistan, HBV in general Pakistani population, HBV in Pediatric population, HBV virus in young population applied for recruitment, $\mathrm{HBV}$ in blood donors, HBV virus in pregnant women, HBV in muti-transfused Pakistani population, HBV in IDU Pakistani population, HBV in Pakistani health care workers, injection use in Pakistan, role of barbers in viral transmission, HBV induce HCC, awareness about HBV in Pakistani population and HBV genotypes in Pakistan. Inclusion criteria entailed the studies demonstrating the prevalence, genotypes, and risk factors associated with transmission of HBV in Pakistani population while the studies with incomplete references were excluded. One hundred eighty nine different articles/abstracts/ reports were obtained from the literature search, out of which 83 published between 1996 and November 2009 were included in this study.

\section{Analysis}

Table 1 includes various reports showing the percent prevalence of HBV in different groups.

Table 1. Studies showing the prevalence of hepatitis B virus in different population groups.

\begin{tabular}{|c|c|c|c|c|c|}
\hline & 1st author & Region & Method & Population & \%age \\
\hline \multirow[t]{6}{*}{ General population } & Alam et al. [9] & Different localities & MEIA & 1300 & $4 \%$ \\
\hline & Abdulla et al. [10] & Karachi & EIA & 35257 & $4.92 \%$ \\
\hline & Abdulla et al. [10] & Sindh & EIA & 1776 & $2.19 \%$ \\
\hline & Chaudhari et al. [11] & Rawalpindi & ELISA & 2056 & $2.28 \%$ \\
\hline & Tanvir et al. [12] & Lahore & ICT & 203 & $2.46 \%$ \\
\hline & Noorali et al. [13] & Karachi & ELISA/ICT & 4000 & $4.50 \%$ \\
\hline \multirow[t]{4}{*}{ Peds } & Agboatwala et al. [14] & Karachi & ELISA & 236 & $2.97 \%$ \\
\hline & Khan et al. [15] & Lahore & ELISA & 538 & $3.35 \%$ \\
\hline & Jafri et al. [16] & Karachi & ELISA & 3533 & $1.80 \%$ \\
\hline & Aziz et al. [17] & Karachi & EIA & 380 & $1.90 \%$ \\
\hline \multirow[t]{7}{*}{ Recruitment } & Ali et al. [18] & Pakistan & ELISA & 5371 & $3.53 \%$ \\
\hline & Mirza et al. [19] & Pakistan & ELISA & 15550 & $3.24 \%$ \\
\hline & Sharif et al. [20] & Pakistan & ELISA & 2558 & $2.80 \%$ \\
\hline & Alam et al. [21] & Punjab & ELISA & 2038 & $4.86 \%$ \\
\hline & Altaf et al [22] & Sindh, & ELISA & 2835 & $7.30 \%$ \\
\hline & Butt et al. [23] & Pakistan & ELISA & 5707 & $2.90 \%$ \\
\hline & Azam et al. [24] & Pakistan & ELISA & 3320 & $4.80 \%$ \\
\hline \multirow[t]{18}{*}{ Blood Trnasfusion } & Mujeeb et al. [25] & Karachi & ELISA & 839 & $4.90 \%$ \\
\hline & Syed AM [26] & Karachi & 一 & 18448 & $2.20 \%$ \\
\hline & Mujeeb et al. [27] & Karachi & ELISA & 612 & $2.21 \%$ \\
\hline & Ahmad et al. [28] & Abbotabad & ELISA & 960 & $1.55 \%$ \\
\hline & Khattak MF [29] & Rawalpindi & ELISA & 103858 & $3.30 \%$ \\
\hline & Mumtaz et al. [30] & Rawalpindi & ICT & 580 & $5.86 \%$ \\
\hline & Rehman et al. [31] & Punjab & 一 & 1176284 & $2.26 \%$ \\
\hline & Khan et al. [32] & Liaquatpur & 一 & 1426 & $5.40 \%$ \\
\hline & Asif et al. [33] & Northern Pakistan & MEIA & 3187 & $2.51 \%$ \\
\hline & Ahmad et al.[34] & Peshawar & MEIA & 4000 & $1.90 \%$ \\
\hline & Asif et al.[ 33] & Northern Pakistan & MEIA & 243 & $0.82 \%$ \\
\hline & Aktar et al. [35] & Karachi & ELISA & 351309 & $2.00 \%$ \\
\hline & Fayyaz et al. [36] & Bahawalpur & ELISA & 27938 & $2.69 \%$ \\
\hline & Jehangir et al. [37] & Multan & ELISA & 25631 & $4.93 \%$ \\
\hline & Chaudhary et al. [38] & Rawalpindi & MEIA & 1428 & $2.45 \%$ \\
\hline & Aziz MS [39] & Baltistan & MEIA & 850 & $8.40 \%$ \\
\hline & Mujeeb et al. [40] & Karachi & ELISA & 7325 & $4.70 \%$ \\
\hline & khan et al.[41] & Abbotabad & ELISA & 1630 & $2.02 \%$ \\
\hline
\end{tabular}


Table 1. Studies showing the prevalence of hepatitis B virus in different population groups (continued).

\begin{tabular}{|c|c|c|c|c|c|}
\hline & 1st author & Region & Method & Population & $\%$ age \\
\hline \multirow{12}{*}{ Pregnant woman } & Khan et al. [42] & Rawalpindi & ICT & 140,369 & $2.31 \%$ \\
\hline & Khan et al. [43] & Quetta & MEIA & 1474 & $4.80 \%$ \\
\hline & Bhatti et al.[44] & Karachi & ELISA & 966 & $2.16 \%$ \\
\hline & Mehnaz et al. [45] & Karachi & ICT & 245 & $3.26 \%$ \\
\hline & Kazmi et al .[46] & Islamabad & $\begin{array}{l}\text { RPHA/RIA/EL } \\
\text { ISA }\end{array}$ & 6225 & $4.00 \%$ \\
\hline & Hakeem et al. [47] & RahimYar Khan & ELISA & 450 & $12 \%$ \\
\hline & Rana et al. [48] & Lahore & & 1000 & $1.80 \%$ \\
\hline & Yousafani et al. [49] & Hyderabad & ELISA/ICT & 103 & $12.62 \%$ \\
\hline & Ahmad et al. [50] & Bahawalpur & ELISA & 300 & $12.30 \%$ \\
\hline & Ali et al. [51] & Karachi & ELISA/EIA & 25482 & $1.57 \%$ \\
\hline & Sami et al. [52] & Karachi & EIA & 5902 & $4.60 \%$ \\
\hline & Sheikh SM [53] & Karachi & ICT & 2592 & $0.34 \%$ \\
\hline \multirow{5}{*}{$\begin{array}{l}\text { Health care } \\
\text { workers }\end{array}$} & Mujeeb et al. [54] & Karachi & ELISA & 114 & $7.50 \%$ \\
\hline & Rehman et al. [55] & Lahore & ELISA & 95 & $5 \%$ \\
\hline & Naz et al. [56] & Muzaffar abad & ELISA & 199 & $4.10 \%$ \\
\hline & Aziz et al. [57] & Karachi & ELISA & 250 & $2.40 \%$ \\
\hline & Sarwar et al. [58] & Abbottabad & ELISA & 125 & $2.40 \%$ \\
\hline \multirow[t]{6}{*}{ Multi transfused } & Muhammad et al. [59] & Peshawar & ELISA & 80 & $7.50 \%$ \\
\hline & Hussain et al. [60] & Peshawar & ELISA & 40 & $5 \%$ \\
\hline & Khokher et al. [61] & Islamabad & ELISA & 97 & $12.40 \%$ \\
\hline & Shah et al. [62] & NWFP & ELISA & 250 & $8.40 \%$ \\
\hline & Malik et al. [63] & Lahore & ELISA & 100 & $4 \%$ \\
\hline & Rehman et al. [64] & Lahore & ELISA & 60 & $1.7 \%$ \\
\hline \multirow[t]{4}{*}{ IDUs } & Ghauri et al. [65] & Karachi & ELISA & 133 & $4 \%$ \\
\hline & Altaf et al. [66] & Sindh & ELISA & 161 & $7.50 \%$ \\
\hline & Achakzai et al. [67] & & ELISA & 50 & $6 \%$ \\
\hline & Alam et al. [68] & Karachi & ELISA & 250 & $22.40 \%$ \\
\hline
\end{tabular}

In the present analysis, we calculated weighted mean of each population using formula:

$$
\bar{x}=\frac{\sum_{i=1}^{n} w_{i} x_{i}}{\sum_{i=1}^{n} w_{i}}
$$

where $\mathbf{x}_{\mathbf{i}}$ and $\mathbf{w}_{\mathbf{i}}$ represent weighted mean and weights. Standard error of mean (SE) was calculated as follows:

$$
S E_{\bar{x}}=\frac{s}{\sqrt{n}}
$$

where $\mathbf{s}$ and $\mathbf{n}$ indicate standard deviation and number of studies. Result of each population group is presented in the form of mean SE with $95 \%$ confidence interval (CI).

\section{Prevalence of hepatitis $B$ virus}

Six different studies showed the percentage prevalence of $\mathrm{HBV}$ is $4.61 \pm 0.73 \%$ in general adult population [9-13], four different studies showed a percentage prevalence of $2.04 \pm 0.47 \%$ in pediatrics [14-17]. In Pakistan, military recruits undergo HBV screening before induction. Seven different studies showed the percentage prevalence of $3.73 \pm 0.63 \%$ in young population applied for military recruitment [18-24]. Blood donations are usually taken from young and healthy individuals, twenty-one different studies showed the percentage prevalence of $2.33 \pm 0.46 \%$ in blood donors [25-44]. Nine different studies showed the percentage prevalence of $2.5 \pm 2.04 \%$ in pregnant women [45-53]. 
Health care workers are usually dealing with blood and blood related product and are at high-risk of getting infections. Five different studies showed the percentage prevalence of $3.89 \pm 0.97 \%$ in health care workers [54-58]. Hemophilic and thalassemic patients are exposed to multiple transfusions during their life; five different studies showed the percentage prevalence of $7.94 \pm 1.49 \%$ in multi-transfused population [59-64]. Injecting drug users extensively exchange needles and are at high risk of getting infections by needle sharing, four different studies showed the percentage prevalence of $12.86 \quad 4.52 \%$ in injecting drug users [65-68].

\section{Genotypes}

HBV is classified into eight genotypes (A-H) based on nucleotides sequence comparison of whole genome and there is $8 \%$ or more sequence divergence between these genotypes. In 2007, it was reported in two different studies that $62.5 \%$ and $65.34 \%$ of HBV patients had genotype D [9,68]. Three different studies in 2008 showed that $64 \%, 83.3 \%$, and $93.2 \%$ of HBV patients had genotype $\mathrm{D}[13,69,70]$. Baig et al in 2009 reported that $70 \%$ of HBV patients had genotype D [71]. Three different studies showed that the most dominant co-infection is of genotype $\mathrm{A}$ and $\mathrm{D}[9,69,71]$.

\section{Risk factors \\ Transfusions}

Proper selection and screening of donor is a key factor to ensure a safe blood supply. Incidence of $\mathrm{HBV}, \mathrm{HCV}$, and HIV is higher in hidden paid or professional donors. Safe donors are those who had no risk factor in their medical history and are repeatedly negative on screening [11]. The dangers of blood transfusions are compounded by poverty. Safe blood transfusions require organized infrastructure, well-educated staff, continuous supply of electricity and availability of expensive equipments and reagents. All these things are usually lacking at a majority of blood banks in developing countries, which was the reason that many blood banks were storing the blood outside the WHO recommended conditions. At some blood banks, the screening of the selective blood samples takes place and is dependent upon the recipient's willingness to pay for the cost of the screening tests. It is reported in 2000 , that $95 \%$ of blood banks have proper facilities for the screening of Hepatitis B virus, 55\% have HIV screening, and
23\% have HCV screening system [72]. It is likely that the condition is improved nowadays.

\section{Needles}

The number of estimated injections per person per year ranged from 8.2 to 13.6 in Pakistani population, which are highest among the developing countries, out of which $94.2 \%$ are unnecessary [73]. In 2000, WHO recommended that the countries should design the strategies to change the behavior of both patients and health care workers to decrease the overuse of injections [74]. Numerous factors are linked with incidence of needle injuries from the health care workers. The most common factors are two- handed recapping and the unsafe collection and disposal of sharp waste. Between 2002 and 2007, 1382 needle stick injuries were observed at Aga Khan University hospital Pakistan. The highest number of injuries were observed from junior doctors (28.5\%) followed by registered nurses (20.4\%). Nineteen percent of injuries were reported during blood collection [75].

\section{Barbers}

It is reported from Bangladesh, Pakistan, India, Iran, Israel and Italy that HBV can be transferred by blade sharing and barber related instruments [76]. In developing countries like Pakistan, most of the barbers have weak educational background and they are unaware of transmission of diseases from their shops [77]. Janjua and Nizamy reported that Barbers have very weak or no sterilization practice, yet they are involved in circumcision and minor surgeries, and playing a key role in transmission of HBV [78]. Barbers are accidently exposed to blood and bodily fluids of their customers and have high-risk of getting infections [79]. It was reported from Casablanca in 2001 that $2 \%$ of barbers were HBV and 5\% of them were HCV positive [80].

\section{Awareness}

Knowledge about risk factors, vaccination, and treatment of HBV was very poor. It was reported by Alum et al. that only $10.5 \%$ of people knew that HBV can be spread by toothbrush sharing, $4.9 \%$ knew that it can be transmitted by tattooing or ear/nose piercing, and only $20.3 \%$ knew that vaccine for HBV is available. Forty percent of people have heard advertisement about a hepatitis cure from homeopathic doctors. Concrete efforts are required, 
both at local and national level, to educate the masses about the various risk factors associated with hepatitis B transmission [81-83].

\section{Vaccination}

Developed countries have succeeded in reducing the risk of Hepatitis B virus spread by interrupting some of the known risk factors involved in its transmission and through massive HBV vaccinations. The vaccine against HBV is available in most of developing countries including Pakistan, but its high cost limits the widespread use. Pakistan has also initiated the universal HBV vaccination for neonates through its expanded program of immunization with the assistance of Global Alliance for Vaccines and Immunization [84]. According to WHO-UNICEF estimates, $73 \%$ of neonates were vaccinated against HBV in 2008 [85]. Efforts are needed to start vaccination programs in adults to decrease the future burden of HBV from Pakistani population.

\section{Hepatocellular carcinoma}

Hepatocellular carcinoma (HCC) represents approximately $6 \%$ of all new cancer cases diagnosed worldwide with relative high incidence rates in Asia and Africa. Chronic hepatitis B and C are strongly linked with the development of HCC [86]. HCC is more prevalent in men than in women. This suggests that estrogen play an important role in its development [87]. Baig et al. [88, 89] reported in 2007 that 4.7\% of HBV positive patients had cirrhosis/HCC, while in 2009, it was reported that $3 \%$ of HBV patients had HCC.

\section{Conclusion}

This article reviews the prevalence, genotypes and risk factors associated with Hepatitis B virus in Pakistani Population. The prevalence of HBV was 2 to $5 \%$ in different general population groups, while high prevalence was observed in multi-transfused and IDU groups. This high prevalence was due to lack of proper screening for blood transfusions and reuse of needles. Most dominant genotype of HBV was D. Vaccination program is only for neonates. Many blood banks were storing the blood outside the WHO recommended conditions. Unnecessary injection use and needle stick injuries were very high. Barbers have weak or no sterilization practice yet, they were involved in minor surgeries. Awareness regarding various risk factors involved in HBV transmission was very weak.
Massive awareness and vaccination programs are required to decrease the future burden of HBV from Pakistani population

\section{Acknowledgement}

This work was supported by Higher Education Commission of Pakistan PhD Scholarship, Pak-US Science and Technology Cooperative Program (IQ) and HEC grant 829 (IQ). The authors have no conflict of interest to report.

\section{References:}

1. Zaki H, Darmstadt GL, Baten A, Ahsan CR, Saha SK. Seroepidemiology of hepatitis B and delta virus infection in Bangladesh. J Trop Pediatr. 2003; 49:371-4.

2. Lavanchy D. Hepatitis B virus epidemiology, disease burden, treatment, and current and emerging prevention and control measures. J Viral Hepat. 2004; 11:97-107.

3. Pakistan country profile. Pakistan: World Health Organization. (Accessed 2009 Jul 23). Available at http:// www.whopak.org/pakprofile.htm.

4. Andre F. Hepatitis B epidemiology in Asia, the Middle East and Africa. Vaccine. 2000; 18:20-2.

5. United Nations Development Program. Human Development Report (1996). New York:Oxford University Press. 1996.

6. Abbas Z, Jafri W, Shah HA, Khokhar N, Zuberi SJ. PGS Consensus statement on management of Hepatitis B virus infection-2003. J Pak Med Assoc. 2004; 54: 150-8.

7. Akhtar S, Rozi S. An autoregressive integrated moving average model for short-term prediction of hepatitis C virus seropositivity among male volunteer blood donors in Karachi, Pakistan. World J Gastroenterol. 2009; 15:1607-12.

8. Waheed Y, Shafi T, Safi SZ, Qadri I. Hepatitis C virus in Pakistan: a systematic review of prevalence, genotypes and risk factors. World J Gastroentrol. 2009; 15:5647-53.

9. Alam MM, Zaidi SZ, Malik SA, Naeem A, Shaukat S, Sharif S, et al. Serology based disease status of Pakistani population infected hepatitis B virus. BMC Infec Dis. 2007; 7:64.

10. Abdulla EM, Abdulla FE. Seropositive HBsAg frequency in Karachi and interior Sindh, Pakistan. Pak J Med Sci. 2007; 23:157-60.

11. Chaudhary IA, Shah SK, Majrooh MA, Alvi AA. Seroprevalence of hepatitis-B and C among patients reporting in surgical OPD at Fauji Foundation Hospital, Rawlapindi. Review of 5 year literature. 
Pak J Med Sci. 2007; 23:514-17.

12. Tanveer A, Batool K, Qureshi AW. Prevalence of hepatitis B and C in university of the Punjab, Quaid-eAzam campus, Lahore. ARPN J Agri Biol Sci. 2008; 3: 30-2.

13. Noorali S, Hakim ST, McLean D, Kazmi SU, Bagasra O. Prevalence of hepatitis $\mathrm{B}$ virus genotype $\mathrm{D}$ in females in Karachi, Pakistan. J Infect Devel Count. 2008; 2:373-8.

14. Agboatwala M, Isomura S, Miyake K, Yamashita T, Morishita T, Akram DS. Hepatitis A, B and C seroprevalence in Pakistan. Indian J Pediatr. 1994; 61: 545-49.

15. Khan HI. A study of seroprevalence of hepatitis B and $\mathrm{C}$ in mothers, and children in Lahore. Pak Ped J. 1996; 20:163-6.

16. Jafri W, Jafri N, Yakoob J, Islam M, Tirmizi SFA, Jafar T, et al. Hepatitis B and C: prevalence and risk factors associated with seropositivity among children in Karachi, Pakistan. BMC Infect Dis. 2006; 6:101.

17. Aziz S, Muzaffar R, Hafiz S, Abbas Z, Zafar MN, Naqvi SA, et al. helicobacter pylori, hepatitis viruses A, C, E, antibodies and HBsAg-prevalence and associated risk factors in pediatric communities of Karachi. J Coll Physicians Surg Pak. 2007; 17:195-8.

18. Ali N, Khattak J, Anwar M, Tariq WZ, Nadeem M, Irfan $\mathrm{M}$, et al. Prevalence of hepatitis B surface antigen and $\mathrm{C}$ antibodies in young healthy adults. Pak J Pathol. 2002; 13:3-6.

19. Mirza I A, Mirza SH, Irfan S, Siddiqi R, Tariq WZ, Asif. Sero prevalence of Hepatitis B and C in young Adults seeking recruitment in armed forces. Pak Armed Forces Med J. 2006; 56:192-7.

20. Sharif TB, Tariq WZ. Seroprevalence of Hepatitis B and C in healthy adult male recruits. Pak J Pathol. 2006; 17:142-6.

21. Alam M, Tariq WZ, Akram S, Qureshi TZ. Frequency of hepatitis B and C in central Punjab. Pak J Pathol. 2006; 17:140-1.

22. Altaf C, Akhtar S, Qadir A, Malik KZ, Ahmed P, Tariq WZ. Frequency of hepatitis B and C among healthy adult males from central Sind. Pak J Pathol. 2007; 18: 113-5.

23. Butt T, Ami MS. Seroprevalence of hepatitis B and c infections among young adult males in Pakistan. East Med Health J. 2008; 14:791-7.

24. Azam N, Mufti K, Zafar N. Frequency of Hepatitis $\mathrm{B} \& \mathrm{C}$ in young male recruits from rural Pakistan. Pak Armed Forces Med J. 2009; 2:59-64

25. Mujeeb SA, Mehmood K. Prevalence of HBV, HCV and HIV infections among family blood donors. Ann Saudi Med. 1996; 16:702-3.

26. Syed AM. Prevalence of HBV, HCV and HIV infections among family blood donors in Karachi, Pakistan. Int Conf AIDS. 1998; 12:391.

27. Mujeeb SA, kausar A, Khalid M. Seroprevalence of HBV, HCV and HIV among college first time volunteer blood donors. J Pak Med Assoc. 2000; 5:269-70.

28. Ahmad F, Shah SH, Tariq M, Khan JA. Prevalence of hepatitis B carrier and HIV in healthy donors at Ayub teaching hospital. Pak J Med. 2000; 39:91-2.

29. Khattak MF. Seroprevalence of Hepatitis B, C and HIV in blood donors in northern Pakistan. J Pak Med Assoc. 2002; 52:398-402.

30. Mumtaz S, Rehman MU, Muzaffar M, Hassan M, Iqbal W. Frequency of seropositive blood donors for hepatitis B, C and HIV viruses in railway hospital Rawalpindi. Pak J Med Res. 2002; 41:51-3.

31. Rehman MU, Akhtar GN, Lodhi Y. Transfusion transmitted HIV and HBV infections in Punjab, Pakistan. Pak J Med Sci. 2002; 8:18-25.

32. Khan MA, Rehman A, Ashraf M, Ali A, Ahraf M, Ditta A. Prevalence of HBV, HCV and HIV in blood donors at Liaquetpur. Profess Med J. 2006; 13:23-6.

33. Asif N, Khokhar N, Ilahi F. Seroprevalence of HBV, HCV and HIV infection among voluntary non remunerated and replacement donors in northern Pakistan. Pak J Med Sci. 2004; 20:24-8.

34. Ahmad J, Taj AS, Rahim A, Shah A, Rehman M. Frequency of hepatitis B and $\mathrm{C}$ in healthy blood donors of NWFP: A single centre experience. J Post Med Inst. 2004; 18:343-52.

35. Akhtar S, Younus M, Adil S, Hassan F, Jafri SH. Epidemiologic study of chronic hepatitis B virus infection in male volunteer blood donors in Karachi, Pakistan. BMC Gastroenterology. 2005; 5:26.

36. Fayyaz M, Khan MA, Qazi MA, Chaudhary GMD, Ahmed G. Hepatitis B, C and HIV: sero-prevalence of infection in blood donors. Profess Med J. 2006; 13: 632-6.

37. Jehangir W, Ali F, Shahnawaz U, Iqbal T, Qureshi HJ. Prevalence of hepatitis B, C and HIV in blood donors of south Punjab. Esculapio. 2006; 2:67.

38. Chaudhary IA, Samilluah, Khan SS, Masood R, Sardar MA, Mallhi AA. Seroprevalence of hepatitis $\mathrm{B}$ and $\mathrm{C}$ among the healthy blood donors at Fauji Foundation Hospital, Rawalpindi. Pak J Med Sci. 2007; 23:64-7.

39. Aziz MS. Prevalence of Anti hepatitis C antibodies and hepatitis B surface antigen in healthy blood 
donors in Baltistan. Pak Armed Forces Med J. 2006; 56:189-91.

40. Mujeeb SA, Nanan D, Sabir S, Altaf A, Kadir M. Hepatitis B and C infection in first-time blood donors in Karachi - a possible subgroup for sentinel surveillance. East Mediterr Health J. 2006; 12:735-41.

41. Khan MS, Jamil M, Jan S, Zardad S, Sultan S, Sahibzada AS. Prevalence of hepatitis ' $\mathrm{B}$ ' and ' $\mathrm{C}$ ' in orthopedics patients at Ayub teaching Hospital Abbottabad. J Ayub Med Coll Abbottabad. 2007; 19: 82-4.

42. Khan ZT, Asim S, Tariq Z, Ehsan IA, Malik RA, Ashfaq B, et al. Prevalence of transfusion transmitted infection in healthy blood donors in Rawalpinid district, Pakistan - a five year study. Int J Pathol. 2007; 5:21-5.

43. Khan ZA, Aslam MI, Ali S. The frequency of hepatitis $\mathrm{B}$ and $\mathrm{C}$ among volunteer blood donors in Balochistan. Hep Mon. 2007; 7:73-6.

44. Bhatti FA, Ullah Z, Salamat N, Ayub M, Ghani E. Anti-hepatitis B core antigen testing, viral markers, and occult hepatitis B virus infection in Pakistani blood donors: implications for transfusion practice. Transfusion. 2007; 47:74-9.

45. Mehnaz A, Hashmi H, Syed S, Kulsoom. Hepatitis B markers in mothers and its transmission in newborn. J Coll Physic Surg Pak. 2002; 12:240-2.

46. Kazmi K. Ghafoor A, Qureshi W. Mother-infant transmission of hepatitis B in Pakistan. Pak J Med Res. 2006; 42:152-6.

47. Hakeem A, Khan MS, Abdullah M, Rehman MA, Hashmi MI. Prevalence of HbSAg and anti HCV in pregnant ladies attending antenatal clinic at sheikh Zayed Medical complex, Rahim Yar Khan. Esculapio. 2006; 2:8-10.

48. Rana G, Akmal N, Akhtar N. Prevalence of hepatitis B in pregnant females. Ann King Edward Med Coll. 2006; 12:313.

49. Yousfani S, Mumtaz F, Memon A, Memon MA, Sikandar R. Antenatal screening for hepatitis B and $\mathrm{C}$ virus carrier state at a university hospital. J Liaquat Uni Med Health Sci. 2006; 5:24-7.

50. Ahmad A, Khichi GQK, Rehman A. Hepatitis markers; its transmission in newborns from mothers. Profess Med J. 2007; 14:307-11.

51. Ali HS, Memon MA. Prevalence of hepatitis B infection in pregnant women in a tertiary care hospital. Infect Dis J. 2007; 16:35-8.

52. Sami S, Korejo R, Bhutta SZ. Prevalence of hepatitis B and C: a Jinnah postgraduate medical centre experience. J Obstet Gynaecol Res. 2009; 35:533-38.

53. Sheikh SM. Hepatitis B and C: value of universal antenatal screening. J Coll Physicians Surg Pak. 2009; 19:179-82.

54. Mujeeb SA, Khatri Y, Khanani R. Frequency of parenteral exposure and seroprevalence of $\mathrm{HBV}, \mathrm{HCV}$, and HIV among operation room personnel. J Hosp Infect. 1998; 38:133-7.

55. Rehman K, Khan AA, HaiderZ, Shahzad A, Iqbal J, Khan RU, et al. Prevalence of seromarkers of HBV and HCV in health care personnel and apparently healthy blood donors. J Pak Med Assoc. 1996; 46: 152-4.

56. Naz S, Ahmad M, Asghar H. Prevalence of Hepatitis ' $\mathrm{B}$ ' among hospital personnel in combined military hospital (CMH) Muzzafarabad. Int J Agri Biol. 2002; 4: 227-30.

57. Aziz S, Memon A, Tily HI, Rasheed K, Jehangir K, Quraishy MS. Prevalence of HIV, hepatitis B and C amongst health workers of civil hospital Karachi. J Pak Med Assoc. 2006; 56:48-50.

58. Sarwar J, Gul N, Idris M, Anis-ur-Rehman, Farid J, Adell MY. Seroprevalence of hepatitis B and hepatitis $\mathrm{C}$ in health care workers in Abbottabad. J Ayub Med Coll Abbottabad. 2008; 20:27-9.

59. Mohammad J, Hussain M, Khan MA. Frequency of hepatitis B and C infection in thalassemic children. Pak Paed J. 2003; 27:161-4.

60. Hussain M, Khan MA, Jan M, Jan A. Frequency of hepatitis B and C in hemophiliac children. Pak Pead J. 2003; 27:157-60.

61. Khokhar N, Naz F. Hepatits B surface antigenemia in patients on hemodialysis. Rawal Med J. 2004; 29:18-21.

62. Shah SMA, Khan MT, Zahour Ullah, Ashfaq NY. Prevalence of hepatitis B and hepatitis C virus infection in multitransfused thalassemia major in North West Frontier Province. Pak J Med Sci. 2005; 21:281-3.

63. Malik N, Hussain Z. Marker of viral hepatitis in hemophiliacs. Biomedica. 2006; 22:48-50.

64. Rahman M, Lodhi Y. Prospects and future of conservative management of beta thalassemia major in adeveloping country country. Pak J Med Sci. 2004; 20:105-12.

65. Ghauri AK, Rehman N, Shah SA, Memon MA. Seroprevalence of HIV, HBV, HCV and syphilis in injecting drug users at Karachi. Int Conf AIDS. 2002; 14:7-12.

66. Altaf A, Shah SA, Zaidi NA, Memon A, Nadeem-urRehman, Wray N. High risk behaviors of injection drug users registered with harm reduction programme 
in Karachi, Pakistan. Harm Reduct J. 2007; 14:7.

67. Achakzai M, Kassi M, Kasi PM. Seroprevalences and co-infections of HIV, hepatitis $\mathrm{C}$ virus and hepatitis B virus in injecting drug users in Quetta, Pakistan. Trop Doct. 2007; 37:43-5.

68. Alam MM, Zaidi SZ, Shaukat S, Sharif S, Angez M, Naeem A, et al. Common genotypes of hepatitis B virus prevalent in injecting drug abusers(addicts) of North West Frontier Province of Pakistan. Vir J. 2007; 4:63.

69. Baig S, Siddiqui AA, Chakarvarty R, Moatter T, Unnissa T, Nazr-ul-hasnain. Phylogenetic analysis of hepatitis B virus in Pakistan. J Coll Physicians Surg Pak. 2008; 18:688-94.

70. Ahmed CS, Wang A, Bin Z, Chen J, Kamal M, Hou J. Hepatitis B virus genotypes, subgenotypes, precore, and basal core promoter mutations in the two largest provinces of Pakistan. Gastroenterol Hepatol. 2008; 24:569-73.

71. Baig S, Siddiqui A, chakarvarty R, Moattar T. Hepatitis B virus subgenotypes D1 and D3 are prevalent in Pakistan. BMC Res Notes. 2009; 2:1.

72. Luby SP, Qamruddin K, Shah AA, Omair A, Pahsa O, Khan AJ, et al. The relationship between therapeutic injections and high prevalence of hepatitis C infection in Hafizabad. Pak Epidemiol Infect. 1997; 119:349-56.

73. Zafar A, Habib F, Hadwani R, Ejaz M, Khowaja K, Khowaja R, et al. Impact of infection control activities on the rate of needle stick injuries at a tertiary care hospital of Pakistan over a period of six years: an observational study. BMC Inf Dis. 2009; 9:78.

74. Altaf A, Janjua NZ, Hutin Y. The cost of unsafe injections in Pakistan and challenges for prevention program. J Coll Physic Surg Pak. 2007; 16:622-4.

75. World Health Organization. Unsafe injection practices having serious large-scale consequences. Press Release WHO/14. Geneva: WHO: 2000:1-2.

76. Waheed Y, Saeed U, Safi SZ, Chaudhry WN, Qadri I. Awareness and risk factors associated with barbers in transmission of hepatitis B and C from Pakistani population: barber's role in viral transmission. Asian
Biomed. 2010; 4:435-42.

77. Khaliq AA, Smego RA. Barber shaving and bloodborne disease transmission in developing countries. S Afr Med J. 2005; 95:94-6.

78. Janjua NZ, Nizamy MA. Knowledge and Practices of barbers about hepatitis B and C transmission in Rawalpindi and Islamabad. J Pak Med Assoc. 2004; 54: 116-9.

79. Candan F, Alagozlu H, Poyraz O, Sumer H. Prevalence of hepatitis B and C virus infection in barbers in Sivas region of Turkey. Occup Med. 2002; 52:31-4.

80. Zahraoui-Mehadji M, Baakrim MZ, Laraqui S, Laraqui O, El Kabouss Y, Verger C, et al. Infectious risks associated with blood exposure for traditional barbers and their customers in Morocco. Sante. 2004; 14:211-6.

81. Alam M, Tariq WZ. Knowledge, attitudes and practices about hepatitis B and C among young healthy males. Pak J Pathol. 2006; 17:147-50.

82. Talpur AA, Memon NA, Solangi RA, Ghumro AA. Knowledge and attitude of patients towards Hepatitis B and C. Pak J Surg. 2007; 23:162-5.

83. Zuberi BF, Zuberi FF, Vasvani A, Faisal N, Afsar S, Rehman J, et al. Appraisal of the knowledge of internet users of Pakistan regarding hepatitis using on-line survey. J Ayub Med Coll Abbottabad. 2008; 20:91-3.

84. World Health Organization: Hepatitis B. Fact sheet 2000. WHO/204.

85. WHO/UNICEF. Review of National Immunization Coverage.1980-2008. Pakistan. 2009; 7.

86. Raza SA, Clifford GM, Franceschi S. Worldwide variation in the relative importance of hepatitis $B$ and hepatitis $\mathrm{C}$ viruses in hepatocellular carcinoma: a systematic review. Br J Cancer. 2007; 96:1127-34.

87. Demaria N, Manno M, Villa E. Sex hormones and liver cancer. Mol Cell Endocrinol. 2002; 193:59-63.

88. Baig S, Siddiqui AA, Ahmed W, Qureshi H, Arif A. The association of complex liver disorder with $\mathrm{HBV}$ genotypes prevalent in Pakistan. Virol J. 2007; 4:128.

89. Baig S. Gender Disparity in infections of Hepatitis B virus. J Coll Physicians Surg Pak. 2009; 19:598-600. 